\title{
Bilimsel Hikâyelerin 6. Sınıf Öğrencilerinin Akademik Başarılarına ve Bilimin Doğasını
} Anlamalarma Etkisinin İncelenmesi

\author{
Songül Kardaş ${ }^{1}$ \\ Prof. Dr. Fatma Şahin ${ }^{2 *}$
}

Geliş tarihi: 07.02.2020

Kabul tarihi: 01.03.2020

\section{Atıf bilgisi:}

IBAD Sosyal Bilimler Dergisi

Sayı: $7 \quad$ Sayfa: 222-234

Yıl: 2020 Dönem: Yaz

This article was checked by Turnitin.

Similarity Index 22\%

Bu makalede araştırma ve yayın etiğine uyulmusştur.

${ }^{1}$ MEB, Türkiye,

songul.kardas34@gmail.com,

ORCID ID 0000-0001-8248-4878

\author{
${ }^{2}$ Marmara, Türkiye, \\ fsahin@marmara.edu.tr \\ ORCID ID 0000-0002-6291-0013
}

\section{* Sorumlu yazar}

\section{ÖZ}

Bilimsel hikâyeler fen kavramlarının yaşamla bağdaştırılmasını sağlamaktadır. Bilimsel hikâye yazma hem fen öğrenmeyi hem de yazma becerilerinin gelişimini sağlamaktadır. Bilimsel hikayeler öğrencilerin fen öğrenmeye motivasyon ve tutumunu da olumlu yönde etkilemektedir. Araştırmanın amacı; bilimsel hikâyelerin hücre ve organeller konusunda 6.sınıf öğrencilerinin; akademik başarılarına ve bilimin doğasını anlamalarına etkisini incelemektir. Bu araştırmada ön test-son test kontrol gruplu deneysel desen kullanılmıştır. Araştırmanın çalışma grubunu 20172018 eğitim-öğretim yılında İstanbul İli Beyoğlu ilçesinde bir devlet ortaokulunda okuyan 15 'i deney, 15 'i kontrol grubu olmak üzere 30 ortaokul 6.sınıf öğrencisi oluşturmuștur. Araștırmada veri toplama araçları olarak Akademik Başarı Testi ve Bilimin Doğası Ölçeği kullanılmıștır. Araștırmada bilimsel hikayeler 5E ders planının derinleştirme aşamasında uygulanmıştır. Veriler SPSS 25.0 programı ile analiz edilmiştir. Çalışma sonucunda bilimsel hikayelerin öğrencilerin akademik başarılarını istatistiksel olarak anlamlı bir şekilde artırdığı görülmüştür. Bilimin doğasını anlamada ise istatistiksel olarak anlamlı bir gelişme görülememiștir.

Anahtar Kelimeler: Bilimsel hikâyeler,5E, akademik başarı, bilimin doğası 
Investigation of the Effect of Scientific Stories on 6th Grade Students' Academic Achievements and Understanding the Nature of Science

\author{
Songül Kardaş ${ }^{1}$ \\ Prof. Dr. Fatma Şahin ${ }^{*}$
}

First received: 07.02 .2020

Accepted: 01.03.2020

\section{Citation:}

IBAD Journal of Social Sciences

Issue: 7

Pages: 222-234

Year: 2020

Session: Summer

This article was checked by Turnitin. Similarity Index 22\%

${ }^{1}$ MEB, Türkiye, songul.kardas34@gmail.com, ORCID ID 0000-0001-8248-4878

${ }^{2}$ Marmara, Türkiye, fsahin@marmara.edu.tr ORCID ID 0000-0002-6291-0013

* Corresponding Author

\begin{abstract}
Scientific stories enable science concepts to be reconciled with life. Scientific story writing provides both the learning of science and the development of writing skills. Scientific stories have positive effects on students' motivation and attitude towards learning science. Purpose of the research is to examine the impact of scientific stories about cells and organelles on the 6th grade students' academic achievement and understanding of the nature of science. In this research, experimental design with pretest-posttest control group was used. The study group of the study consisted of sixth grade students, attending a public secondary school in Beyoğlu district of Istanbul in 2017-2018 academic year that 15 of them were experimental and 15 of them were control group. In the research, Academic Achievement Test and Nature of Science Scale were used as data collection tools. Scientific stories were applied during the deepening phase of the $5 \mathrm{E}$ lesson plan. Data were analyzed with SPSS 25.0 program. As a result of the study, it was seen that scientific stories increased students' academic achievement statistically. There was no statistically significant improvement in understanding the nature of science.
\end{abstract}

Key Words: Scientific stories, 5E, academic achievement 


\section{GÍRIS}

Yazma, fikirlerin aktarılması, iletişim kurma ve etkileşimi sağlayan bir süreçtir. Yazma, bilimsel okuryazarlık ve sorgulama için bir araçtır (Hayes ve Flower, 1986; Yore, 2000).

\section{Bilimsel Okuryazarlık ve Bilimin Doğası}

Öğrencilerin bilimi ve doğasını öğrenmeleri, gelecekteki bilim adamlarının yaratıcı ve eleştirel bakış kazanması açısından önemli olduğu belirtilmektedir (Longbotton ve Butler, 1999). Bilimin doğası pek çok ülkenin öğretim programlarında eğitsel bir amaç olarak gösterilmektedir (Lederman, 2007). Bu nedenle bilimin doğasının öğretilmesi için çeşitli araçlara başvurulmaktadır (Hogan, 2000). Fen eğitiminde bir öğrenme aracı olan öğrenme amaçlı yazma, öğrencilerin fen öğrenmelerine yardım eden güçlü bir araç olarak kabul edilmektedir (Lewin ve Wagner, 2006). NRC, (1996) göre yazma fen eğitiminin temel araçlarındandır ve bilimsel bağlamı anlamak için temel unsur olarak Kabul edilmektedir. İlkokuldan üniversiteye kadar çeşitli eğitim düzeyleri üzerine yapılan araştırmalar, bilimsel ve teknik yazmayı öğrenmenin bilim eğitimini artırmadaki önemini vurgulamıştır (Yore, 2000).

Bilimin doğası bilim okuryazarlığını geliştirmenin önemli bir yoludur. Bilimsel okur-yazarlık; bilimin doğası hakkında yeterli bir anlayışa sahip olma, bilimsel süreç becerilerine sahip olma, bilim, teknoloji ve toplum ilişkisinin farkında olunması ve bu bilgi ve anlayışın uygulamaya aktarılmasını içermektedir (NRC 1996; Ryder 2001). Bilimsel okur-yazarlık kavramının, bilimin doğası, bilimsel süreç becerileri ve bilimsel içerik olmak üzere üç bileşenden oluştuğu ifade edilebilir. Bu bileşenlerin en önemlisinin bilimin doğası kavramı olduğu ifade edilmektedir (Bell and Lederman 2003).

Roberts (2007) bilimsel okuryazarlık için 2 vizyon önermiştir. Vizyon I; bilim konusunun önemine (yani, bir bilim adamının bakış açısıyla bilimsel okuryazarlık) odaklanırken, Vizyon II; bilimin toplumdaki günlük yaşamlarındaki rolünü vurgulamaktadır. OECD, (2006) "uluslararası öğrenci değerlendirme programı" olan PISA vizyon II'ye dikkat çekmektedir (Fensham, 2009). Bilim okuryazarlığının tanımlanmasında, "bilimle ilgili konuları ve bilimsel düşünmeyi yansıtmaya istekli olma” konusuna son zamanlarda vurgu yapılması önemli bir gelişmedir (OECD, 2006, s. 23).

\section{Bilimsel Hikayeler}

Bilimsel hikâye; bilimsel bilginin hikâye içine gömüldüğü hikâyelerdir. Bu tür hikâyelere biyohikâye de denilmektedir. Pek çok mevcut bilim programı, öğrencilerin yaşamla bağdaşdırılmış kavramsal öğrenmesini önemsemektedir (Goodrum ve Rennie, 2001; Linder, 2007; Tytler, 2007). Aynı zamanda, bilim eğitiminde bilimsel okuryazarlığın geliştirilmesi ana hedef olmaya devam etmektedir (Sadler, 2005). Bu nedende bir çok eğitimci ilk ve orta okulda bilimsel okuryazarlığı teşvik eden öğretme ve öğrenme stratejilerinin geliştirilmesinin önemini belirtmişlerdir (Prain, 2006). Öğrencilerin bilim okuryazarı bir birey olabilmeleri için sosyobilimsel (örneğin, küresel 1sınma, temiz yakıtlar, genetiği değiştirilmiş gıdalar, su mevcudiyeti ve kalitesi, biyogüvenlik) konularda bilimsel hikâyeler yazdırmanın faydalı olacağı bildirilmiştir. Bilimsel hikâye yazan öğrenci sadece konuyla ilgili yazmaya olan ilgisini görmekle kalmaz, aynı zamanda yeni bir şey öğrendiğini de görür. Bu da öğrencilerin bilime karşı gittikçe azalan katılımının ve ilgisinin tekrar arttırılabileciğini göstermektedir. Özellikle ortaokul öğrencileri (yani, 6-9. Sınıflar), bilime daha az ilgi duyduklarından, sinıfta bilim etkinliklerine daha az katılmaktadırlar (Goodrum ve Rennie, 2001; Osborne ve Collins, 2010; Woolnough, 1994). Bu, fen eğitimcileri için önemli bir konudur. Çünkü bilime ilgisiz öğrenciler, sürdürülebilir bir gelecek için bilimsel ve teknolojik problem çözme becerileri düşük vatandaşlar olacaklardır (Tytler, 2007).

Bilimsel hikâyeler öğrencilerin fen öğrenmeye olumlu tutum geliştirmelerini ve kavramsal bilgiyi öğrenmede bilim okuryazarlık anlayışı geliştirmelerini sağlanmaktadır (Tytler, 2007). Bilimsel hikâyeler aynı zamanda öğrencilerde bilim öğrenmeye karşı özgüven geliştirmektedir (Hampton \& Mason, 2003). Bilim hakkında yazmak, konuşmak ve okumak, bilimsel okuryazarlığın arzulanan amaçlarındandır (Prain ve Waldrip, 2009). Öğrencinin yazdı̆̆ 1 bilimsel hikâyeler öğretmenler tarafindan okunup analiz edilerek öğrencilerin zihinlerindeki bilgi ağları tespit edilebilir (Prain, 2006). Bu bakımdan bilimsel hikâye yazma hem öğretim hem de değerlendirme aracı olarak kullanılabilir. 
Daha önceleri bilimsel yazma aşina ve sıklıkla kullanılabilirken, günümüzde teknolojinin gelişmesiyle öğrenciler artık yazmak istememektedirler (Wellington ve Osborne, 2001).

Bilimsel hikayelerin öğrencilerin bilimsel okuryazarlığını gelişmesi yanında sosyobilimsel konulara karşı bilimsel düşünme kapasitelerini de arttırmaktadır. Sosyobilimsel konular üzerine yazma, öğrencilerin ahlaki, etik ve epistemolojik yönelimlerinin gelişmesine yardım ederken, bilimsel bağlamda gömülü (örtük) etik kararlar alma süreçlerini de geliştirmektedir. Bu tür bilimsel yazma faaliyetleri öğrencilerin verileri yorumlama, kanıtları analiz etme, tartışma becerilerinin gelişimine ve bilimsel bilgi geliştirmelerine firsatlar sağlamaktadır (Zeidler ve ark. 2009; Sadler ve Zeidler, 2005; Sadler, 2009).

Hikâyelerin, öğrencilerin fen öğrenmeye ilgisini teşvik ederek, onlara anlamlı, tutarlı ve akılda kalıcı bağlamlar sunabilmektedir (Millar ve Osborne, 1998; Boström, 2006). Rowcliffe (2004), hikayelerin eğlenceli ve ilginç olması koşuluyla, bilim öğrenmeye olumlu katkı sağlayabileceğini öne sürmektedir. Hikâye yazma yoluyla, bilim ve bilim teorileri, öğrencilerin anlamalarını kolaylaştıracak ve motivasyonu arttıracak bir bağlamda sunulabilir (Weber, 1990; Klassen, 2006). Koening ve Zorn (2002), hikâye yazmanın teori ve pratiği birbirine bağlamak için bir yöntem olacağını, Abrahamson (1998), hikayede somut örnekler kullanıldığından bilimsel kavramlar arasında daha anlamlı ilişkiler kurulabileceğini belirtmişlerdir. Yine bir çok araştırmacı (Tao, 2003; Stinner, McMillan, Metz, Jilek \& Klassen, 2003), bilimsel hikâyelerin tüm eğitim seviyelerinde uygun olacağını belirtirken, Rowcliffe (2004) ise ilkokul düzeyinde daha uygun olacağını iddia etmektedir.

Hikâye yazma ve anlatma, diğer öğretim stratejileri gibi bir öğrenme öğretme stratejisidir. Boström (2006) bilimsel hikâyelerin bağlam temelli yaklaşımlar, probleme dayalı öğrenme gibi bir öğrenme strateji olduğunu, bu nedenle uygulamalı etkinlikler (hands-on) ve sorgulama (1nquiry) temelli olduğunu belirtmiştir. Rowcliffe (2004), hikâye yazma ve anlatmayı, fen eğitiminde bilimsel bir problem sunmak, karmaşık bir süreci açıklamak ve günlük hayattan gerçek bilimsel sorunları açıklamak için kullanılabileceğini bildirmiştir. Ayrıca, hikâye yazma ve anlatımı, tarihsel bağlamları birleştirerek, belleği destekleyen bir zihinsel uyarıcı görevi yapmaktadır. Bilimi eğlenceli hale getirerek öğrencileri duygusal olarak motive etmektedir. Hikâye yazma ve anlatma bilimi öğretmenin tek yolu değildir, ancak iyi bir öğretmenin birçok öğretim stratejisi kullandığını ve hikâye anlatımın onlardan biri olduğunu vurgulanmaktadır.

Hikâyelerin eğitime bu olumlu katkıları yanında zorlukları da vardır. Öğretmenlerin hikâyeleri kullanma biçimi, bunun çekici ve anlamlı olup olmayacağını belirlemektedir (Boström, 2006). Hikâyenin yapısı da bilimsel kavramların doğru bir şekilde öğrenilmesinde önemlidir (Hadzigeorgiou, 2006). Hikayede öğretilecek bilimsel içeriği açık ve sade bir şekilde sunulmalıdır. Diğer bir konu da, hikâyelerin bilimin gerçeklerine uygun kurgulanması gerekir. İyi planlanmamış hikâyeler kavram yanılgılarına sebep olabilir (Boström 2006; Kazemek, Louisell ve Wellike (2004). Kavram yanılgıları hem metinden hem de kullanılan görsellerden kaynaklanabilir (Kazemek, Louisell, and Wellike (2004).

Literatürde bilimsel hikâyeler dört başlık altında sınıflandırılmıştır (Milne, 1998): 1. Heroik bilim hikâyeleri (Kahramanlık bilimi hikâyeleri); bilimin gelişimine katkıda bulunan insanların hayatının anlatıldığı hikayelerdir. 2. Keşif ve bilimsel öyküler: Bazı bilimsel bulguların tesadüfen bulunduğunu anlatmaktadır. 3. Açıklayıcı bilim hikâyeleri: Bilim ve bilimsel bilginin herkes için araştırmaya ve soruşturmaya açık bir disiplin olduğunu vurgulamaktadır. 4. Politik bilim hikâyeleri: Farklı kültürlerin ve farklı topluluklarda bilimin gelişimini incelemektedir.

Moitra (2014) bilimsel hikâye yazma için 6 basamak önermiştir. Bunlar; 1. Uygun Bir Hikâye Oluşturma; Bilimsel hikâye yazmak için konu seçmede bilim kitaplarından, videolardan ve belgesellerden faydalanılabilir. 2. Öğrenme Amaç ve Hedeflerini Belirleme; Bu, hikâye anlatımı sürecinin çok önemli bir parçasıdır. Öğrencilerin hangi kavramları öğrenmesi istiyorsa onlar belirlenmelidir. Öğretmen tarafından belirlenen her hikâyenin kendine özgü öğrenme hedefleri vardır. 3. Hikâye Çerçevesini Oluşturmak; Öğrenme hedeflerini belirledikten sonra hikâye öğrenme hedefleri etrafında yapılandırılır. 4. Bilimsel/Eğitimsel İçerik Eklemek; Bilimsel / eğitimsel içerik daha sonra ögrenme hedeflerine göre uygun yerlere eklenir. Çeşitli ders kitaplarından, evraklardan ve çevrimiçi 
kaynaklardan gelen materyallerden faydalanılabilir. 5. Görsel İçerik, Bağlantılar Ve Sorgulamaya Dayalı Sorular Ekleme; Bir sonraki adım, öğrencilerin ilgisini çekmek için çoklu ortam içeriğinin yanı sıra daha fazla bilgi toplamak için öğrencilerin kullanabileceği kaynaklar eklenir. Öğretmen tarafından oluşturulan sorular da hikâyeye eklenebilir. 6. Sınıfta Hikâyeyi Test Etme; Bu son adım, öğrenciyi tartışma ve katılıma teşvik etmek için tasarlanmıştır. Bu aşamada öğretmen gerek duyarsa değişiklikler önerebilir.

Bilimsel hikayelerin, bilimsel okuryazarlık, bilimin doğası ve bilimsel bilginin öğrenilmesindeki önemi gözönüne alınarak bu çalışma tasarlanmıştır. Buna göre araştırmanın amac1; bilimsel hikayelerin hücre ve organeller konusunda 6. sınıf öğrencilerinin, akademik başarılarına ve bilimin doğasını anlamalarına etkisini araştırmaktır.

\section{Problem ve Alt Problemler}

"Bilimsel hikâyelerin hücre ve organeller konusunda 6.sınıf öğrencilerinin; akademik başarılarına ve bilimin doğasını anlamalarına etkisi var mıdır?"

Bu problem cümlesine bağlı olarak araştırmamızın alt problemleri aşağıda ifade edilmiştir:

1. Bilimsel hikâyelerin öğrencilerin akademik başarılarına etkisi var mıdır?

2. Bilimsel hikâyelerin, öğrencilerin bilimin doğasını anlamalarına etkisi var mıdır?

\section{YÖNTEM}

Araştırma, bilimsel hikâye yazma destekli eğitimin öğrencilerin akademik başarı ve bilimin doğasını anlamalarına etkisini incelemek için ön test-son testli, deney ve kontrol gruplu deneysel olarak tasarlanmış nicel bir çalışmadır.

\section{Çalışma Grubu}

Araştırmanın çalışma grubunu 2017-2018 eğitim-öğretim y1lında İstanbul İli Beyoğlu ilçesinde bir devlet ortaokulunda okuyan ortaokul 6.sınıf öğrencileri oluşturmaktadır. Sınıf öğretmenlerinin yönlendirmesiyle benzer özelliğe sahip olan iki sınıf belirlenmiş ve bu sınıflar deney ve kontrol grubu olarak seçilmiştir. Araştırmada 15 öğrenci deney, 15'i kontrol grubu olmak üzere 30 öğrenci ile çalışılmıştır. Deney ve kontrol grupları seçkisiz olarak belirlenmiştir.

\section{Veri Toplama Araçları}

Araştırma nicel veri toplama araçları kullanılmıştır. Bu araçlar akademik Başarı Testi ve Bilimin Doğası Ölçekleridir.

Akademik Başarı Testi (A.B.T); Başarı testi geliştirme sürecinde önce kaynak taraması, soruların oluşturulması, kazanımlara uygunluk incelenmiştir. Sonra pilot çalışma yapılmış ve uzman görüşü alındıktan sonra teste son hali verilmiştir. Test bu haliyle 57 7. Sınıf öğrencisine uygulanarak geçerlik güvenirlik çalışması yapılmıştır. Test Hücre ve Organeller konusu ile ilgili 10 çoktan seçmeli sorudan oluşmuştur. Testin ortalama güçlüğü 0,62 ; cronbach alpha katsayısı 0.70 olarak hesaplanmıştır. Testin madde güçlük ve madde ayırt edicilik indeksleri Tablo 1 ve 2'de verilmiştir.

Tablo 1. Akademik Başarı Testinin Pilot Uygulamasının Madde İstatistikleri

\begin{tabular}{ccc}
\hline Madde Numarası & Madde Güçlüğ̈̈ & Madde Ayırt Edicilik İndeksi \\
\hline 1 & 0,93 & 0,19 \\
2 & 0,77 & 0,63 \\
3 & 0,14 & 0,06 \\
4 & 0,61 & 0,63 \\
5 & 0,65 & 0,75 \\
6 & 0,58 & 0,31 \\
7 & 0,75 & 0,63 \\
8 & 0,23 & 0,06 \\
9 & 0,74 & 0,63 \\
10 & 0,77 & 0,63 \\
\hline
\end{tabular}


Tablo 1'e göre madde güçlük indeksleri incelendiğinde değerlerin 0,93 ile 0,14 arasında değiştiği ve 1.maddenin en kolay, 3.maddenin ise en zor madde olduğu görülmektedir. Testin ortalama güçlüğü 0,62 olarak hesaplanmıştır ve orta güçlükte olduğu söylenebilir. \%27'lik alt üst grup yöntemi ile hesaplanan madde ayırt edicilik indekslerine bakıldığında 0,06 ile 0,75 arasında değiştiği görülmektedir. Büyüköztürk’e (2011) göre, madde ayırt edicilik indeksi 0,20' den düşük olan maddeler teste alınmamalı ve 0,20 ile 0,30 arasındaki maddeler gerekli ise tekrar gözden geçirilerek teste alınmalıdır. Ayırt edicilik indeksi 0,30'un üzerinde olan maddeler ise teste alınabilir. Bu sebeple 1.madde gözden geçirilerek teste alınmış ve 3 ve 8 numaralı maddeler testten çıkarılmıştır. Madde sayısı sekize düştüğü için testten atılan maddelerin kapsadığı konulardan iki yeni soru başarı testine eklenmiştir. İki yeni sorunun yer aldığı başarı testi ile yeniden pilot uygulama yapılmıştır. Aynı okulda okuyan 25 öğrenci ile yapılan pilot uygulamadan elde edilen akademik başarı testi ve ölçeklere ait Cronbach's Alpha değerleri Tablo 2'de verilmiştir.

Tablo 2. Akademik Başarı Testinin ve Ölçeklerin Güvenirlik Değerleri

Ölçek Madde Sayısı Cronbach's Alpha

$\begin{array}{lll}\text { Akademik Başarı Testi } & 10 & 0,70 \\ \text { İlköğretim Öğrencilerinin Bilimin } & 16 & 0,73 \\ \text { Doğasını Anlama Ölçeği } & & \end{array}$

Tablo 2'ye göre akademik başarı testinin güvenirlik katsayısı 0,70 ; ilköğretim öğrencilerinin bilimin doğasını anlama ölçeğinin güvenirlik katsayısı 0,73 olarak hesaplanmıştır. Güvenirlik katsayısının 0,70 ve daha büyük olması kullanılan ölçme aracının güvenirliğinin sağlandığını ve maddeler arası iç tutarlılığının olduğunu göstermektedir (Büyüköztürk, 2011).

Bilimin Doğası Ölçeği (B.D.Ö); Bilimin Doğası Ölçeği (B.D.Ö); Araştırmada Çoban ve Ergin (2008)'in ölçeği kullanılmıştır. Bilimin Doğası Ölçeği, 5'li likert tipinde hazırlanmıştır. Testin cronbach alpha katsayısı 0.73 olarak hesaplanmıştır.

\section{Araştırmanın Uygulanması}

Araştırma öncesinde öğrencilere eğitim programının amacı, içeriği ve yapacakları etkinlikler hakkında bilgi verilmiştir. Sonrasında iki gruba da akademik başarı testi ve bilimin doğası ölçeği ön test olarak uygulamıştır. Ön testlerin uygulanmasının ardından deney ve kontrol grubunda dersler 5E modeline göre planlanmıştır. Deney grubunda 5E ders planının derinleştirme aşamasında bilimsel hikâye yazma etkinliği eklenmiştir. Öğrenciler bilimsel hikayeleri yazarken Moitra, (2014a)'nın belirttiği bilimsel hikaye oluşturma basamaklarından faydalanmışlardır. Bu basamaklar şunlardır;

1.Öğrenme amaç ve hedeflerini belirleme

2. Hikaye çerçevesini konun amaçlarına göre oluşturmak

3. Uygun bir hikaye oluşturma

4. Bilimsel/Eğitimsel içerik eklemek

5: Görsel içerik, bağlantılar ve sorgulamaya dayalı sorular ekleme

6: Sinıfta hikayeyi okuyarak değerlendirme

Uygulamanın sonunda deney grubu ve kontrol grubuna ABT ve BDAÖ son testler uygulanmıştır.

\section{Verilerin Analizi}

Araştırmanın hipotezini ve alt problemlerini test etmek için kullanılan analizler SPSS 25.0 ve Microsoft Excel yardımıyla yapılmıştır. Demografik bilgiler için tanımlayıcı istatistik yöntemlerinden frekans ve yüzde hesaplanmıştır. Madde istatistikleri hesaplanırken Microsoft Excel'de madde güçlüğü ve madde ayırt edicilik indeksleri elde edilmiştir. Akademik başarı testinin ve ölçeklerin güvenirlik analizi için Cronbach's Alpha katsayısı hesaplanmışır. Akademik başarı testinden ve 
ölçeklerden elde edilen toplam puanlar için betimsel istatistiklerden yararlanmış ve hangi hipotez testinin kullanılacağına karar vermek için çarpıklık ve basıklık katsayıları yardımı ile dağılımın normalliği test edilmiştir. Dağılımlar normal olduğu için deney ve kontrol grubu arasındaki farka bakmak için bağımsız örneklem t-testi, uygulamanın etkisini araştırırken ön test ve son test arasındaki farka bakmak için ise bağımlı örneklem $t$ testi kullanılmıştır.

\section{BULGULAR}

Bu çalışmada bilimsel hikâye yazmanın öğrencilerin Hücre ve Organeller konusundaki akademik başarılarına ve bilimin doğasını anlamalarına etkisi incelenmiştir. Elde edilen bulgular aşağıda tablolar halinde verilmiştir.

\section{Öğrencilerin Akademik Başarı Testi Ve Bilimin Doğasını Anlama Ölçeğine Ait Bulgular}

$\mathrm{Bu}$ bölümde araştırmanın nicel analiz yöntemlerinin sonuçlarına yer verilmiştir. Çarpıklık ve basıklık katsayıları +1.5 ve $-1,5$ arasında olan dağılımlar normal dağılım kabul edilebilir. Kullanılacak hipotez testini belirlemek için elde edilen çarpıklık ve basıklık katsayıları ve başarı testi ile ölçeklerin toplam puanlarına ait betimsel istatistik sonuçları Tablo 3 ve 4 'te verilmiştir.

Tablo 3. Akademik Başarı Testinin ve Ölçeklerin Toplam Puanların Deney Grubuna Ait Betimsel Analiz Sonuçları

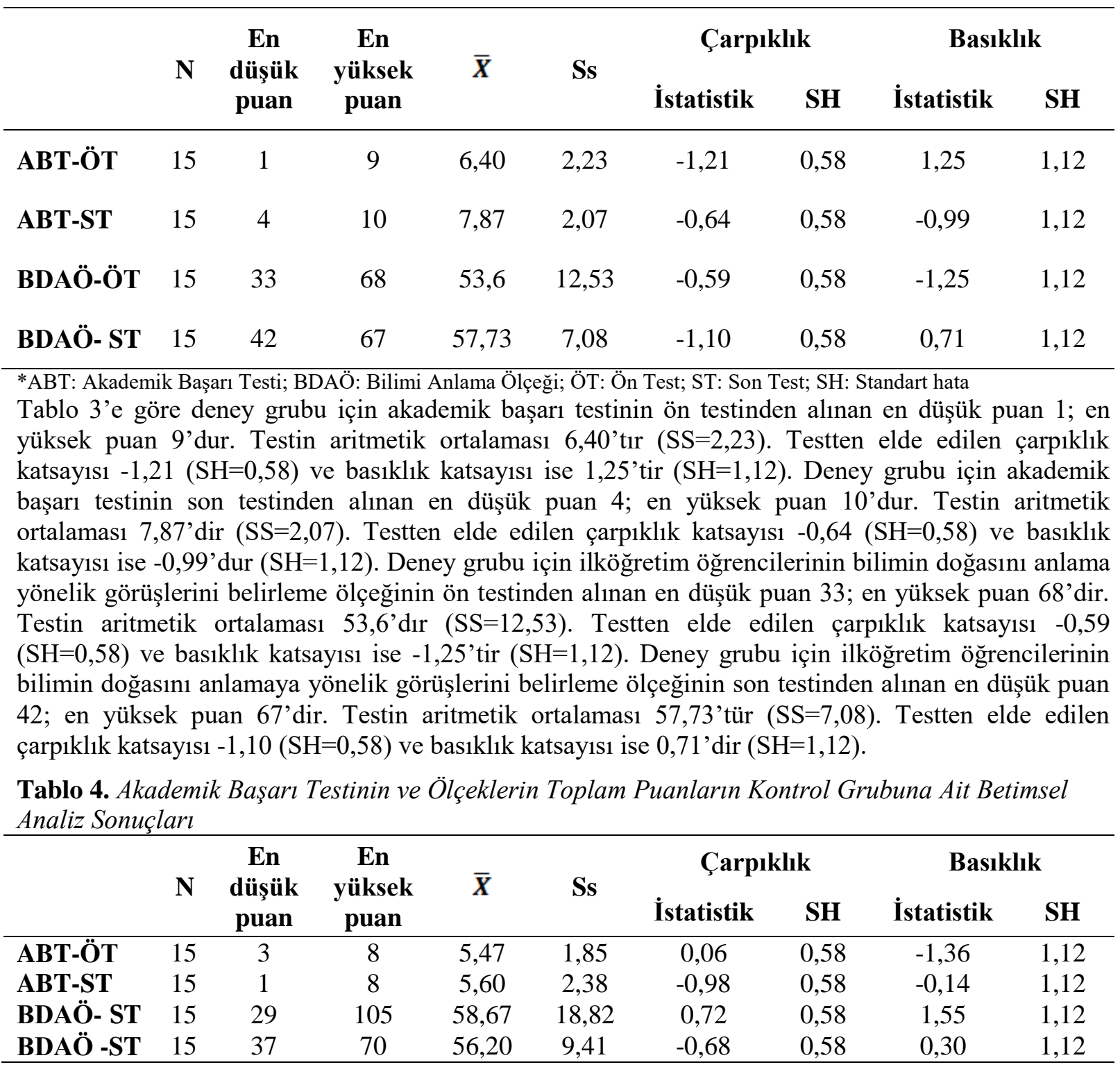


Tablo 4'e göre kontrol grubu için akademik başarı testinin ön testinden alınan en düşük puan 3; en yüksek puan 8 'dir. Testin aritmetik ortalamas1 5,47'dir $(\mathrm{SS}=1,85)$. Testten elde edilen çarpıklık katsayıs1 0,06 $(\mathrm{SH}=0,58)$ ve basıklık katsayısı ise -1,36'dır $(\mathrm{SH}=1,12)$.Kontrol grubu için akademik başarı testinin son testinden alınan en düşük puan 1; en yüksek puan 8 'dir. Testin aritmetik ortalaması $5,60$ 'dır ( $\mathrm{SS}=2,38)$. Testten elde edilen çarpıklık katsayıs1 $-0,98(\mathrm{SH}=0,58)$ ve basıklık katsayısı ise 0,14 'tür $(\mathrm{SH}=1,12)$. Kontrol grubu için ilköğretim öğrencilerinin bilimin doğasını anlamaya yönelik görüşlerini belirleme ölçeğinin ön testinden alınan en düşük puan 29; en yüksek puan 105 'tir. Testin aritmetik ortalaması 58,67'dir (SS=18,82). Testten elde edilen çarpıklık katsayısı $0,72(\mathrm{SH}=0,58)$ ve basıklık katsayısı ise $1,55^{\prime}$ tir $(\mathrm{SH}=1,12)$. Kontrol grubu için ilköğretim öğrencilerinin bilimin doğasını anlamaya yönelik görüşlerini belirleme ölçeğinin son testinden alınan en düşük puan 37 ; en yüksek puan 70 'tir. Testin aritmetik ortalaması 56,20 'dir $(\mathrm{SS}=9,41)$. Testten elde edilen çarpıklık katsayısı $0,68(\mathrm{SH}=0,58)$ ve basıklık katsayısı ise 0,30 'dur $(\mathrm{SH}=1,12)$.

Tablo 5. Ön Test Uygulamalarına Ait Bağımsız Örneklem t Testi Sonuçları

\begin{tabular}{|c|c|c|c|c|c|c|}
\hline \multirow{2}{*}{$\begin{array}{l}\text { Bağımlı } \\
\text { Değişken }\end{array}$} & \multicolumn{2}{|c|}{$\begin{array}{c}\text { Deney Grubu } \\
\qquad(\mathrm{n}=15)\end{array}$} & \multicolumn{2}{|c|}{$\begin{array}{c}\text { Kontrol Grubu } \\
\qquad(\mathrm{n}=15)\end{array}$} & \multirow[t]{2}{*}{$\mathbf{t}$} & \multirow{2}{*}{$\mathbf{p}$} \\
\hline & $\overline{\boldsymbol{X}}$ & Ss & $\overline{\boldsymbol{X}}$ & Ss & & \\
\hline ABT-ÖT & 6,40 & 2,23 & 5,47 & 1,85 & 1,25 & 0,22 \\
\hline BDAÖ-ÖT & 53,60 & 12,53 & 58,67 & 18,82 & $-0,87$ & 0,39 \\
\hline
\end{tabular}

Tablo 5'de yer alan bağımsız örneklem t testi sonuçlarına göre akademik başarı testi ön test puanları deney ve kontrol grubu için istatistiksel olarak farklılaşmamaktadır $(\mathrm{t}(28)=1,25 ; \mathrm{p}>0,05)$. Akademik başarı testi ön test puanlarına göre deney grubunun $(\bar{X}=6,40)$ ve kontrol grubunun $(\bar{X}=5,47)$ ortalamaları arasında istatistiksel olarak anlamlı farklılık bulunmamaktadır. İlköğretim öğrencilerinin bilimin doğasını anlamaya yönelik görüşlerini belirleme ölçeği ön test puanları deney ve kontrol grubu için istatistiksel olarak farklılaşmamaktadır ( $\mathrm{t}(28)=-0,87 ; \mathrm{p}>0,05)$. İlköğretim öğrencilerinin bilimin doğasını anlamaya yönelik görüş̧erini belirleme ölçeği ön test puanlarına göre deney grubunun $(\bar{X}=53,60)$ ve kontrol grubunun $(\bar{X}=58,67)$ ortalamaları arasinda istatistiksel olarak anlamlı farklilik bulunmamaktadir.

Tablo 5'de yer alan sonuçlara göre uygulamaya başlamadan önce oluşturulan deney ve kontrol grupları arasında akademik başarı, bilimin doğasını anlamaya yönelik görüşleri ve yazma kaygısı becerileri arasında anlamlı farklılık bulunmamaktadır.

Tablo 6. Son Test Uygulamalarına Ait Bağımsız Örneklem t Testi Sonuçları

\begin{tabular}{|c|c|c|c|c|c|c|}
\hline \multirow{2}{*}{$\begin{array}{l}\text { Bağımlı } \\
\text { Değişken }\end{array}$} & \multicolumn{2}{|c|}{$\begin{array}{l}\text { Deney Grubu } \\
\qquad(\mathbf{n}=15)\end{array}$} & \multicolumn{2}{|c|}{$\begin{array}{l}\text { Kontrol Grubu } \\
\qquad(\mathrm{n}=15)\end{array}$} & \multirow[t]{2}{*}{$\mathbf{T}$} & \multirow[t]{2}{*}{$\mathbf{P}$} \\
\hline & $\overline{\boldsymbol{X}}$ & Ss & $\overline{\boldsymbol{X}}$ & Ss & & \\
\hline ABT-ST & 7,87 & 2,07 & 5,60 & 2,38 & 2,78 & $0,01 *$ \\
\hline İÖBDAÖ-ST & 57,73 & 7,08 & 56,20 & 9,41 & 0,50 & 0,62 \\
\hline
\end{tabular}

$* \mathrm{p}<0,05$

Tablo 6'da yer alan bağımsız örneklem $t$ testi sonuçlarına göre akademik başarı testi son test puanları deney ve kontrol grubu için istatistiksel olarak farklılaşmaktadır $(\mathrm{t}(28)=2,78 ; \mathrm{p}<0,05)$. Akademik başarı testi son test puanlarına göre deney grubunun $(\bar{X}=7,87)$ ve kontrol grubunun $(\bar{X}=5,60)$ ortalamaları arasında istatistiksel olarak anlamlı farklılık bulunmaktadır. Başarının deney grubu 
yönüne arttığ1 söylenebilir. İlköğretim öğrencilerinin bilimin doğasını anlamaya yönelik görüşlerini belirleme ölçeğin son test puanları deney ve kontrol grubu için istatistiksel olarak farklılaşmamaktadır $(\mathrm{t}(28)=0,50 ; \mathrm{p}>0,05)$. İlköğretim öğrencilerin bilimin doğasını anlamaya yönelik görüşlerini belirleme ölçeği son test puanlarına göre deney grubunun $(\bar{X}=57,73)$ ve kontrol grubunun $(\bar{X}=56,20)$ ortalamaları arasında istatistiksel olarak anlamlı farklılık bulunmamaktadır.

Tablo7. Akademik Başarı Testi Bağımlı Örneklem t Testi Sonuçları

\begin{tabular}{lccccccc}
\hline \multirow{2}{*}{$\begin{array}{l}\text { Bağımlı } \\
\text { Değișken }\end{array}$} & \multicolumn{2}{c}{ Ön Test } & \multicolumn{2}{c}{ Son Test } & T & P \\
\cline { 2 - 5 } & $\overline{\boldsymbol{X}}$ & Ss & $\overline{\boldsymbol{X}}$ & Ss & & \\
\hline ABT-DG & 6,40 & 2,23 & 7,87 & 2,07 & $-2,30$ & $0,04^{*}$ \\
ABT-KG & 5,47 & 1,85 & 5,60 & 2,38 & $-0,20$ & 0,85 \\
\hline
\end{tabular}

*p<0,05; DG: Deney Grubu; KG: Kontrol Grubu

Tablo 7'de yer alan bağımlı örneklem t testi sonuçlarına göre akademik başarı testinin deney grubu puanları ön test ve son test için istatistiksel olarak farklılaşmaktadır t $(14)=-2,30 ; p<0,05)$. Akademik başarı testi deney grubu puanlarına göre ön testin $(\bar{X}=6,40)$ ve son testin $(\bar{X}=7,87)$ ortalamaları arasında istatistiksel olarak anlamlı farklılık bulunmaktadır. Başarının son test yönüne arttı̆̆ 1 ve bu farkın uygulamadan kaynaklandığı söylenebilir. Akademik başarı testinin kontrol grubu puanları ön test ve son test için istatistiksel olarak farklılaşmamaktadır $(\mathrm{t}(14)=-0,20 ; \mathrm{p}>0,05)$. Akademik başarı testi kontrol grubu puanlarına göre ön testin $(\bar{X}=5,47)$ ve son testin $(\bar{X}=5,60)$ ortalamaları arasında istatistiksel olarak anlamlı farklılık bulunmamaktadır.

Tablo 8. İlköğretim Öğrencilerinin Bilimin Doğasını Anlama Ölçeği Bağımlı Örneklem $t$ Testi Sonuçları

\begin{tabular}{lccccccc}
\hline \multirow{2}{*}{ Bağımlı Değişken } & \multicolumn{2}{c}{ Ön Test } & \multicolumn{2}{c}{ Son Test } & \multirow{2}{*}{ T } & P \\
\cline { 2 - 5 } & $\overline{\boldsymbol{X}}$ & Ss & $\overline{\boldsymbol{X}}$ & Ss & & \\
\hline İÖBDAÖ-DG & 53,60 & 12,53 & 57,73 & 7,08 & $-1,19$ & 0,26 \\
İÖBDAÖ-KG & 58,67 & 18,82 & 56,20 & 9,41 & 0,40 & 0,70 \\
\hline
\end{tabular}

Tablo 8'de yer alan bağımlı örneklem t testi sonuçlarına göre ilköğretim öğrencilerinin bilimin doğasını anlama ölçeğinin deney grubu puanları ön test ve son test için istatistiksel olarak farklılaşmamaktadır t $(14)=-1,19 ; \mathrm{p}>0,05)$. İlköğretim öğrencilerinin bilimin doğasını anlama ölçeği deney grubu puanlarına göre ön testin $(\bar{X}=53,60)$ ve son testin $(\bar{X}=57,73)$ ortalamaları arasında istatistiksel olarak anlamlı farklılık bulunmamaktadır. İlköğretim öğrencilerinin bilimin doğasını anlama ölçeğinin kontrol grubu puanları ön test ve son test için istatistiksel olarak farklılaşmamaktadır $(\mathrm{t}(14)=0,40 ; \mathrm{p}>0,05)$. İlköğretim öğrencilerinin bilimin doğasını anlama ölçeği kontrol grubu puanlarına göre ön testin $(\vec{X}=58,67)$ ve son testin $(\bar{X}=56,20)$ ortalamaları arasında istatistiksel olarak anlamlı farklılık bulunmamaktadır.

\section{TARTIŞMA VE SONUÇ}

Yapılan çalışmada bilimsel hikâyelerle fen eğitiminin öğrencilerin başarısını arttırmada etkili araçlar olduğu sonucuna ulaşılmıştır. Çalışmada başarı ön testinde deney ve kontrol grupları arasında anlamlı farklılık bulunmazken $(\mathrm{p}>0,05)$, başarı son test puanları arasında anlamlı farklılık ortaya çıkmışır $(\mathrm{p}<0,05)$. Kontrol ve deney grubu öğrencilerine uygulanan Başarı ön test-son test puanları karşılaştırıldığında ise hem deney hem de kontrol grubunun ikisinde de öğretim sonrası uygulanan son test lehine anlamlı farkl11ı ortaya çıkmıştır $(p<0,05)$. Bu sonuç kontrol grubunda uygulanan mevcut fen ve teknoloji programının ve deney grubunda uygulanan bilimsel hikaye yazma destekli fen 
eğitiminin her ikisinin de öğrencilerin "Hücre ve Organeller'” ünitesindeki başarılarını arttırdığı, fakat deney grubunda uygulanan bilimsel hikaye yazma destekli eğitiminin öğrenci başarılarını arttırmada daha etkili olduğu şeklinde yorumlanmıştır. Araştırmanın nitel bulguları bilimsel hikâyelerin öğrencilerin akademik başarı üzerindeki olumlu etkisini destekler niteliktedir. Alan yazında akademik başarı değişkeni bakımından bu çalışmadan elde edilen bulgulara benzer sonuçlar ortaya koyan araştırmaların yer aldığı görülmektedir (Akarsu ve ark., 2015). Bilimsel hikâyelerin ve öykü haritalarının kullanılması öğrencilerin daha etkili ve kalıcı öğrendikleri bulmuştur (Gölcük, 2017). Çıralı ve Usluel (2017) yaptıkları çalışmalarında öğrencilerin yazma becerilerinin gelişiminde dijital hikayelerin olumlu etkisi olduğu bulunmuştur.

Yapılan bu çalışmada bilimsel hikâyelerin öğrencilerin bilimin doğasını anlama ile ilgili gelişimlerinin sınırlı kaldığı tespit edilmiştir. Bu durumun nedeni olarak öğrencilerin ilk defa bilimsel bağlamda böyle bir çalışma ile karşılaşmış olmaları, yaşlarının küçük olması, eğitim sistemimizin gerektirdiği sınav kaygısı ile öğrencilerin ezberci sistemi benimsemeleri, fen kitaplarında bilimin doğasına ilişkin etkinliklerin yer almaması, öğretmenlerin bu konuda yeterli donanıma sahip olmaması gösterilebilir.

Alan yazında hikayelerin ve öykülerin bilimin doğasını anlamalarına etkisini inceleyen çalışmalar bulunmaktadır. Yapılan bir çalışmada sosyobilimsel konularda hikâyelerin etkisini incelemiştir. Çalışma sonucunda hikâyelerin öğrencilerin yaşamda karşılaştıkları problemlere çözüm üretmelerini geliştiği bulunmuştur (Gölcük, 2017). Budak ve ark.(2008) da yaptıkları çalışmalarında hikayelerin, öğrencilerin bilimin doğasını almalarını ve derinlemesine düşünmelerini geliştirdiğini bulmuşlardır.

Bilimsel hikayelerin öğrencilerin akademik başarılarını olumlu yönde etkilerken bilimin doğasını anlamalarına da destek olduğu bildirilmiştir. Bilimsel hikayelerin öğrencilerin kavramsal anlayışını, bilimin doğasını anlamayı ve bilimsel okuryazarlığı geliştirdiğini bildirmişlerdir (Norris ve Phillips, 2003; Stephen ve ark., 2011). Bilimsel hikâye yazma öğrencilerin yazmadan keyif almalarını ve bilime karş1 olumlu tutum geliştirmelerini desteklemektedir (Sadler, 2009); Fensham, 2001; Avraamidou ve Osborne, 2009; Wellington ve Osborne (2001). Sosyobilimsel konularda bilimsel hikaye yazmada argumentasyonun büyük yarar sağlayacağı bildirilmiştir (Zeidler, 2009; Avraamidou ve Osborne, 2009).

Milne (1998) çalışmasında, bilimsel hikayeleri sınıflandırmış ve okulda verilen fen eğitimi için önemini vurgulamıştır. Milne'ye (1998) göre, bilim aktarırken hikayeler çok önemlidir ve öğrencilerin dikkatini çekmek için kullanılabilir. Milne, ders kitaplarını inceleyen bir çalışmada, kahramanlık bilimi öyküleri, keşif bilimi öyküleri, bildirimsel bilim öyküleri ve politik olarak doğru bilim öyküleri olmak üzere dört tür bilimsel öykü tanımlamıştır. Bu türlerin her biri, bilimle ilgili belirli bir varsayım kümesini desteklemektedir. Bu varsayımlar, dolaylı olarak hikayenin içinde bilimin gerçekleri olarak sunulmaktadır. Tao (2002), araştırmasında, 7 yaş grubu öğrencilerinin bilimsel öykülere tepkilerini ve öykülerde belirtilen bilimin doğası ile ilgili çıkarımları nasıl yapabileceklerini araştırmıştır. Çalışmanın sonunda, öğrencilerin çoğunluğunun rastgele keşiflerinden elde ettikleri önceki deneyimlerine dayanarak bir bakış açısı geliştirdiği ve bilimsel teorileri gerçeği temsil eden mutlak gerçekler olarak kabul ettiği bulunmuştur. Ayrıca, bilimsel hikayelerin öğrencileri çok etkilediği ve hikayelerde verilen işbirlikli öğrenmenin düşüncelerini ve bilimin doğasını paylaşma konusundaki görüşlerini değiştirdiği görülmüştür. Bilimsel hikâyelerin akademik başarıya etkisi ile ilgili yapılan bir başka çalışmada Dincel (2005) tarafından yapılmıştır. Bu çalışma sırasında öğrencilerden bitmemiş hikâyeleri tamamlamalarını istenmiş ve tamamlanan bu hikâyeler değerlendirilmiştir. Yeşilyurt (2004) bilimsel hikayelere dayanan fen öğretiminin, eğitimin farklı aşamalarında fen öğrenmesinde önemli bir fark yarattığını belirtmişlerdir.

Lederman, (1998) bilimin doğasını etkili bir şekilde öğretmenin zorluklarının bildirmiştir. Bilim tarihi, sosyobilimsel konular gibi gerçek olayları içeren hikayelerin kullanılmasının bilimin doğasını anlamayı kolaylaştıracağını belirtmiştir. Böylece bilimsel bilginin insan umutlarına, beklentilerine, tutkularına ve emellerine bağlı olduğu gerçeğini fark eder. Dahası, hikayelerin kullanımı öğrencilerin bilimsel bilgileri anlamalarına yardımcı olabilir (Hadzigeorgiou, 2016; Norris ve ark., 2005; Corni ve ark., 2010). Bilimsel hikayeler yaşamla bilim arasındaki köprülerdir (Hadzigeorgiou, 2016). Bilimsel hikayelerle bilimin doğasını öğretmede öğrencilerin kendilerini bilim insanı gibi bilim yapabileceği hayallerini kurmaya ve bilimsel araştırma ile tanışmalarına ve bilimin doğasını anlamalarına yardım 
eder (Schiffer ve Gueria, 2015). Heering, (2010) bilimsel hikayelerle bilimsel bilginin geçici doğasını ve en önemlisi hem bilim adamlarının başarılarını hem de başarısızlıklarını görmeleri ve anlamaları için yardım edeceğini bildirmiştir. Bu çalışmada da bilimsel hikaye yazma etkinliklerinin öğrencilerin bilimi doğasını anlamalarını geliştirdiği görülmüştür.

\section{KAYNAKÇA}

Abrahamson, C. E. (1998). Storytelling as a pedagogical tool in higher education. Education, 118(3), $440-452$.

Akarsu, B., Kariper. İ. A. ve Karabulut, H. (2015). The effect of using scientific stories on teaching science and on the academic achievement of the students. Mersin Üniversitesi Eğitim Fakültesi Dergisi, 11(2), 349-365

Avraamidou, L. ve Osborne, J. (2009). The role of narrative in communicating science. International Journal of Science Education, 31, 1683-1707.

Bell, R. L. ve Lederman, N. G. (2003). Understandings of the nature of science and decision making on science and technology based issues. Science Education, 87, 352- 377.

Boström, A. (2006). Sharing lived experience: how upper secondary school chemistry teachers and students use narratives to make chemistry more meaningful. Unpublished $\mathrm{PhD}$ diss., Stockholm Institute of Education Press. Education, 11, 3-13

Budak, E., Köseoğlu F. ve Tümay, H. (2008). Bilimin doğası hakkında paradigma değişimleri ve öğretimi ile ilgili yeni anlayışlar. Gazi Eğitim Fakültesi Dergisi, 28(2), 221-237

Büyüköztürk, Ş. (2011). Sosyal bilimler için veri analizi el kitabı. Ankara: Pegem.

Corni, F., Gilberti, E. ve Mariani, C. (2010). A story as innovative medium for science education in primary school. $\quad 12 \quad$ Mart 2015 tarihinde https://personale.unimore.it/rubrica/pubblicazioni/corni adresinden erişildi.

Çıralı, H. ve Usluel, Y.K. (2017). Eğitsel bağlamda atölye temelli dijital hikâye anlatımı süreci: sorunlar, gereksinimler ve öneriler. 5. Uluslararası Öğretim Teknolojileri ve Öğretmen Ĕ̈itimi Sempozyumu, İzmir.

Çoban, G. ve Ergin Ö. (2008). İlköğretim öğrencilerinin bilimsel bilgiye yönelik görüşlerini belirleme ölçeği. İlköğretim Online Dergisi, 7(3), 706-716.

Dincel, M. (2005). Öyküleme ve deney tekniğinin fen bilgisi dersinde ögrencilerin kavramsal anlama ve başarılarına etkisi. Yayımlanmamış yüksek lisans tezi, Marmara Üniversitesi, Eğitim Bilimleri Enstitüsü, İstanbul.

Fensham, P. J. (2009). Assessment of context-based science education. Paper presented at the annual conference of the Australasian Science Education Research Association, Geelong, Victoria.

Goodrum, D. ve Rennie, L. (2007). Australian school science education national action plan 20082012. Canberra: Department of Education Science and Training.

Gölcük, A. (2017). Bilimsel hikâyelerle desteklenen fen eğitiminin ögrencilerin yaratıcılıkları ve duyuşsal özellikleri üzerindeki etkileri. Yayınlanmamış Yüksek lisans tezi, Hacettepe Üniversitesi Eğitim Bilimleri Enstitüsü, Ankara.

Hampton, N. Z. ve Mason, E. (2003). Learning disabilities, gender, sources of self-efficacy, and academic achievement in high school students. Journal of School Psychology, 41, 101-112.

Hadzigeorgiou, Y. (2016). Imaginative science education: The central role of imagination in science education. 83-119. Cham, Switzerland: Springer International.

Hayes, J. ve Linda, F (1986). Writing research and the writer. American Psychologist, 41, 1106-1113. 
Heering, P. (2010). False friends: What makes a story inadequate for science teaching? Interchange, 41, 323-333.

Hogan, K. (2000). Exploring a process view of students' knowledge about the nature of science. Science Education, 84(1), 51-70

Kazemek, F., Louisell. R. ve Wellike. J. (2004). Children's Stories about Their Natural Worlds: An Exploration from Multiple Perspectives (and an Invitation to Participate). Paper presented at the annual meeting of the national association of research in science teaching, Vancouver, April.

Klassen, S. (2006). Does a science story have heuristic power to promote learning? First International Conference on Story in Science Teaching, Munich.

Koening, J. M. ve Zorn, C. R.(2002). Using storytelling as an approach to teaching and learning with diverse students. Journal of Nursing Education, 41(9), 393-399.

Lederman, N. (1998). The state of science education: Subject matter without context. Journal of Science Education, 3(2). $12 \quad$ May1s 2019 tarihinde http://wolfweb.unr.edu/homepage/jcannon/ejse/lederman.html adresinden erişildi.

Lederman, N. G. (2007). Nature of science: Past, present, and future. In S. K. Abell \& N. G. Lederman (Eds.), Handbook of research on science education (pp.831-879). Mahwah, NJ: Erlbaum.

Linder, D. (2007). Available at SSRN. 20 Mart 2019 tarihinde https://ssrn.com/abstract=1027995 adresinden erişildi.

Longbottom, J. ve Butler, P. (1999). Why teach science? Setting rational goals for science education. Science Education, 83, 473-492.

Millar, R., and J. Osborne (1998). Beyond 2000. Science education for the future. London: School of Education, King's college.

Milne, C. (1998). Philosophically correct science stories? Examining the implications of heroic science stories for school science. Journal of Research In Science Teaching, 35(2), 175-187.

Moitra, K. (2014). The call of the story: innovative approaches in STEM classrooms. Lilly International Conference on College and University Teaching and Learning, EvidenceBased Teaching and Learning. Bethesda, MD.

National Research Council. (1996). National science education standards. Washington, DC: National Academy Press.

Norris, S., Guilbert, S., Smith, M., Hakimelahi, S.ve Phillips, L. (2005). A theoretical framework for narrative explanation in science. Science Education, 89(4), 535-554.

OECD (Organization for Economic Co-operation and Development). (2006). Assessing scientific, reading and mathematical literacy: A framework for PISA 2006. Paris: OECD.

Osborne, J. ve Collins, S. (2010). Pupils' views of the role and value of the science curriculum: a focus-group study. International Journal of Science Education, 23(5), 441-467.

Prain, V., \& Waldrip, B. (2009). Representation and learning in science in Australasia. The world of science education. Ritchie (Ed.), The world of science education: Handbook of research in Australasia. pp. 63-78. Rotterdam: Sense Publishers.

Prain, V. (2006). Learning from writing in secondary science: Some theoretical and practical implications. International Journal of Science Education, 28, 179-201.

Ritchie, S. M., Rigano, D. L. ve Duane, A. (2008). Writing an ecological mystery in class: Merging genres and learning science. International Journal of Science Education, 30, 143-166. 
Roberts, D. A. (2007). Scientific literacy/science literacy. In S. K. Abell \& N. G. Lederman (Eds.), Handbook of research on science education. pp. 729-780. Mahwah, NJ: Lawrence Erlbaum.

Rowcliffe, S. (2004). Storytelling in Science. School Science Review, 86(314), 121-126.

Ryder, J. (2001). Identifying science understanding for functional scientific literacy. Studies in Science Education, 36(1), 1-44

Sadler, T. D. (2009). Situated learning in science education: Socio-scientific issues as contexts for practice. Studies in Science Education, 45, 1-42.

Sadler, T. D. ve Zeidler, D. L. (2005). The significance of content knowledge for informal reasoning regarding socioscientific issues: Applying genetics knowledge to genetic engineering issues. Science Education, 89, 71-93

Schiffer, H. ve Gueria, A. (2015). Electricity a vital force: Discussing the nature of science through historical narratives. Science \& Education, 24, 409-434.

Stephen M. R., Tomas, L. ve Tones M. (2011). Writing stories to enhance scientific literacy. International Journal of Science Education, 33(5), 15 pp. 685-707

Stinner, A., McMillan, B.A., D., Jilek, D, J, M. ve Klassen, S. (2003). The renewal of case studies in science education. Science and Education, 12(7), 617-643.

Tao, P. (2002). A study of students' focal awareness when studying science stories designed for fostering understanding of the nature of science. Research in Science Education, 32(3), 97120.

Tao, P-K. (2003). Eliciting and developing junior secondary students' understanding of the nature of science through a peer collaboration instruction in science stories. International Journal of Science Education, 25(2), 147-171.

Tytler, R. (2007). Re-imagining science education: Engaging students in science for Australia's future. Australian Council for Educational Research. 20 Temmuz 2007 tarihinde http://www.acer.edu.au/documents/AER51_ReimaginingSciEdu.pdf adresinden erişildi.

Weber, S. (1990). The teacher educator's experience: cultural generativity and duality of commitment. Curriculum Inquiry, 20, 141-159.

Wellington, J. ve Osborne, J. (2001). Language and literacy in science education. pp.63-65. Buckingham: Open University Press.

Woolnough, B. E. (1994). Why students choose physics, or reject it. Physics Education, 29(5), 368374.

Yeşilyurt, S. (2004). İlköğretim 4. ve 5. Sınıf öğrencilerinin terazi dengesi ve çözünmeyi hatırlayarak analiz ve sentez yapmada deney ve oyunun etkisi. Illkögrretim Online, 3(1), 11-19.

Yore, L. D. (2000). Enhancing science literacy for all students with embedded reading instruction and writing-to-learn activities. Journal of Deaf Studies and Deaf Education, 5, 105-121.

Zeidler, D. L., Sadler, T. D., Applebaum, S. ve Callahan, B. E. (2009). Advancing reflective judgment through socioscientific issues. Journal of Research in Science Teaching, 46, 74-101. 